\title{
P-13
}

\section{Upper Part of the Maha Oya Catchment Area Water Quality Distribution}

\author{
Matharaarachchi S. and Piyadasa R.U.K.* \\ Faculty of Science, University of Colombo, Colombo 03, Sri Lanka \\ ranjana@geo.cmb.ac.lk
}

\begin{abstract}
Water quality of the Maha Oya stream that runs across the Dolosbage, Rahala and Aranayaka was determined using water samples collected from twenty selected locations. Dug wells in the catchment of the stream were also selected to to identify groundwater quality changes due to water pollution in the river. These locations were selected from systematic sampling points were selected based on $800 \mathrm{~m}$ grid a dug well was selected from the centre of the point or around the centre point in each plot. Geographical Information System (GIS) package ArcGIS10 (Spatial Analysis Tool) was used to identify the spatial changes of water quality in the river and surrounded groundwater pollution area. Water samples were assessed for selected parameter such as Temperature, $\mathrm{pH}$ and Electric Conductivity during the period of 5 month in year 2013. In the all 20 river locations $\mathrm{pH}$ varies from 5.5 to 8 . EC varies from $17 \mu \mathrm{s} / \mathrm{cm}$ to $70 \mu \mathrm{s} / \mathrm{cm}$. The counts of $\mathrm{pH}$ value were significantly lower in the populated area and tea plantation areas than in other locations. A sociological survey was conducted concurrently to study the impact of two communities (Tea state settlement and agricultural) living along the stream bank on water quality and social aspect. The results indicate that $\mathrm{pH}$ near the populated area (Tea state settlement area) is probably due to the large amount of household waste that is discharged directly to the stream. The concluded that decomposition of organic matter produces $\mathrm{CO}_{2}$, which dissolves in water as carbonic acid, thereby lowering the $\mathrm{pH}$.
\end{abstract}

Keywords: GIS, pH, Electrical Conductivity, Catchment 